\title{
MAMMARY ADENOCARCINOMA WITH WIDESPREAD METASTASIS IN A LION (PANTHERA LEO)
}

\author{
Ivica Gjurovski ${ }^{1}$, Monika Dovenska ${ }^{1}$, Slavica Kostadinova Kunovska ${ }^{2}$, \\ Jordanco Milosevski ${ }^{3}$, Vesna Levajkovic Trajkov ${ }^{3}$, Trpe Ristoski ${ }^{1}$ \\ ${ }^{1}$ Faculty of Veterinary Medicine, University "Ss Cyril and Methodius", Lazar Pop \\ Trajkov 5-7, 1000 Skopje, Republic of North Macedonia \\ ${ }^{2}$ Institute of Pathology, Faculty of Medicine, Ss. Cyril and Methodius University, Skopje, \\ Republic of North Macedonia \\ ${ }^{3}$ Zoo Garden Skopje, Republic of North Macedonia
}

Received 17 April 2019; Received in revised form 1 July 2019; Accepted 10 July 2019

\begin{abstract}
A 15 year old female African lion (Panthera leo) was necropsied after its sudden death. The necropsy showed a mammary gland lesion measuring $10 \mathrm{~cm}$ in diameter and numerous white nodules with variable size in the liver, spleen, uterus, lungs and the heart. The histopathological examination showed that the neoplastic formation in the mammary region was a simple tubular carcinoma with metastases on the other organs. Upon immunohistochemical examination, the neoplastic cells expressed cytokeratins while the stroma of the tumour expressed vimentin. The proliferation index Ki-67 was moderate. Based on the macroscopic, histopathological and immunohistochemical findings, the neoplasia was diagnosed as a simple tubular mammary carcinoma.
\end{abstract}

Key words: carcinoma, mammary gland, lion

\section{INTRODUCTION}

Among domestic animals, tumors of the mammary gland are one of the most frequent neoplasms in dogs $(1,2)$ and cats $(3)$. Most of feline mammary tumours are malignant, whie the most frequent types of adenocarcinoma in cats are the tubular, papillary and solid carcinomas $(4,5)$. There is a limited number of reports on mammary neoplasms in nondomestic felid species. According to these reports, mammary adenocarcinomas are the most often form of mammary neoplasia in lions,

Corresponding author: Dr. Ivica Gjurovski, $\mathrm{PhD}$

E-mail address: igjurovski@hotmail.com

Present address: Faculty of Veterinary Medicine, University

"Ss Cyril and Methodius"

Lazar Pop Trajkov 5-7, 1000 Skopje, Republic of North Macedonia

Phone: +38972 570016

Copyright: (C) 2019 Gjurovski I. This is an open-access article published under the terms of the Creative Commons Attribution License which

permits unrestricted use, distribution, and reproduction in any medium, provided the original author and source are credited.

Competing Interests: The authors have declared that no competing interests exist.

Available Online First: 20 July 2019

Published on: 15 October 2019

https://doi.org/10.2478/macvetrev-2019-0019 while less frequent mammary lesions are squamous cell carcinoma, mammary cysts and mammary lobular hyperplasia (6). There are only few case reports of mammary carcinoma in lion (7), but, to our knowledge, there are no reports of mammary carcinoma with widespread metastasis.

The following report presents the postmortem findings of a female lion that died due to carcinoma of the mammary gland that metastasized to most of the internal organs. Here we describe the necropsy, the histopathological and the immunohistochemical findings.

\section{MATERIAL AND METHODS}

Complete necropsy of a 15-year-old female African lion (Panthera leo) was performed not later than 12 hours after the animal's death. The following tissues were collected for further histopathological and immunohistochemical examination: mammary gland tumor, uterus, lungs, liver, spleen, kidneys and intestines. The tissue samples were fixed in $10 \%$ neutral formalin, embedded in paraffin and sectioned at 3-4 $\mu \mathrm{m}$. 
For the purpose of histopathology, the slides were stained with hematoxylin and eosin.

For the purpose of immunohistochemistry, a DAKO Envision kit based on the Peroxidase/ DAB method, was used in order to characterize the primary neoplasm and the metastatic foci. The tissue slides were incubated $20 \mathrm{~min}$ in $3 \%$ $\mathrm{H}_{2} \mathrm{O}_{2}$ to block the endogenous peroxidase. As a pretreatment for this method, for the purpose of antigen retrieval, a citrate buffer $\mathrm{pH}$ 6,0 was used by using heat treatment in microwave at $500 \mathrm{~W}$ during $20 \mathrm{~min}$. Slides were incubated for

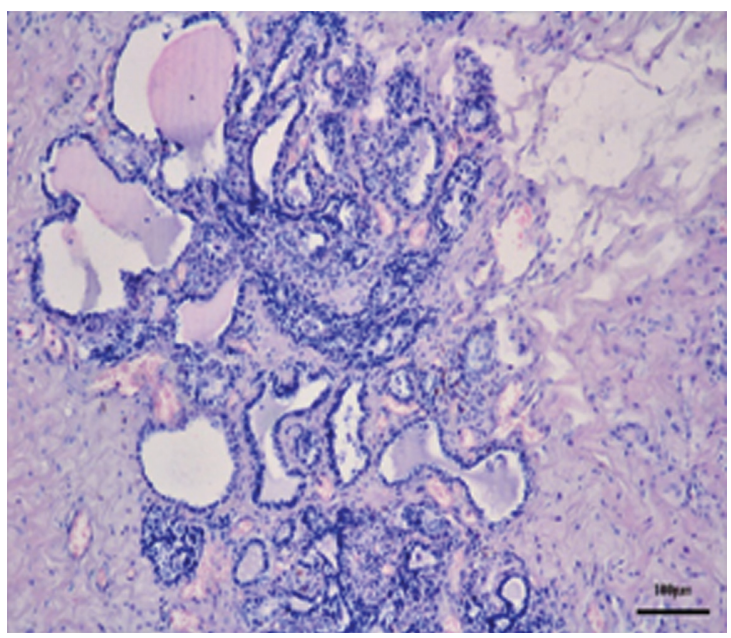

Figure 1. Mamary gland, pleomorphic epithelial mitotic cells (H\&E., Bar-100 $\mu \mathrm{m})$

1 hour at room temperature with the following primary antibodies: mouse monoclonal antibody anti human-vimentine, clone V9 (DAKO), mouse monoclonal antibody anti-human Ki-67 antigen, clone MIB-1 (DAKO) and mouse monoclonal antibody anti-human cytokeratin, as well as clone AE1/ AE3 (DAKO). Subsequently, secondary antibodies labelled with horseradish peroxidase (HRP) were applied to the slides and they were incubated for $20 \mathrm{~min}$. Chromogen, 3.3'- diaminobezidine tetrahidrochloride (DAB - DAKO), which is used for visualization of the reaction, was applied on the slides and incubated for $5 \mathrm{~min}$ at room temperature, after which the slides were washed with PBS and stained with Mayers' hematoxylin for contrasting.

\section{RESULTS}

At necropsy, a massive lesion, measuring $10 \mathrm{~cm}$ in diameter, was noticed subcutaneously in the mammary region. The lesion was white, smooth, firm and poorly demarcated from the surrounding mammary tissue. The abdominal cavity contained about 3 liters of reddish transudate. Many white nodules with diameter between $1 \mathrm{~mm}$ and $2 \mathrm{~cm}$ were found on the liver, spleen, uterus, lungs and the heart. The nodules were firm, and with white and smooth surfaces and cut surfaces. The nodules were present throughout the parenchyma of the organs. The spleen and liver were enlarged, while the nodules on these two organs were largest compared to the rest of the organs. No nodules were found on the peritoneum, nor on the pleura.

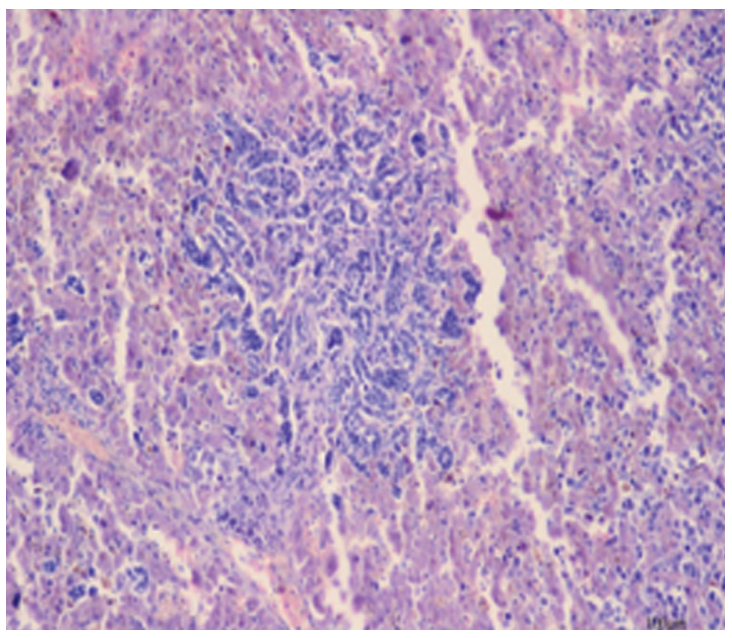

Figure 2. Liver, metastatic nodule

(H\&E., Bar-100 $\mu \mathrm{m})$

The histopathological examination showed massive carcinomatous infiltration in the tissue samples from the mammary gland and the majority of the internal organs. The tumor originated from the mammary gland and its differentiation varied between organs. Many pleomorphic mitotic cells were noticed in the mammary gland (Fig. 1). There were central necroses, as well as inflammatory and hemorrhage areas. The tumor also had a strongly developed scirrhous component. The lungs had metastatic nodules with a diameter of about 5-10 $\mathrm{mm}$, and also interstitial pneumonia (Fig. 3). Metastatic foci were found in the liver (Fig. 2), where lymphocytic granulomas were also observed. The heart had nodular endocarditis and lymphocytic pericarditis. The architecture of the splenic parenchyma was remarkably effaced by many metastatic nodules (Fig. 4). There was a severe endometrial hyperplasia of the uterus with many lymphocyte follicles. The neoplastic nodules in the other organs had the same features to those of the mammary gland tumor. 


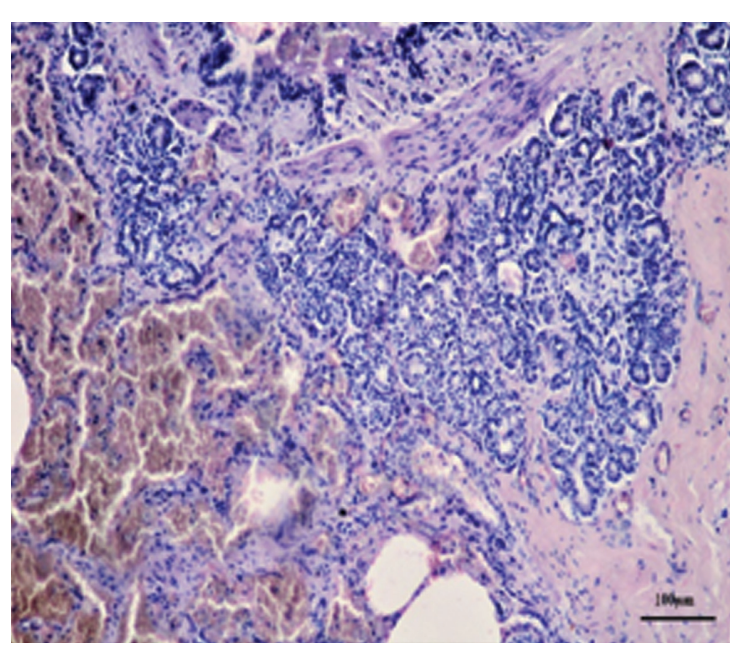

Figure 3. Lungs, interstitial pneumonia, tumor epithelial cells (H\&E., Bar-100 $\mu \mathrm{m})$

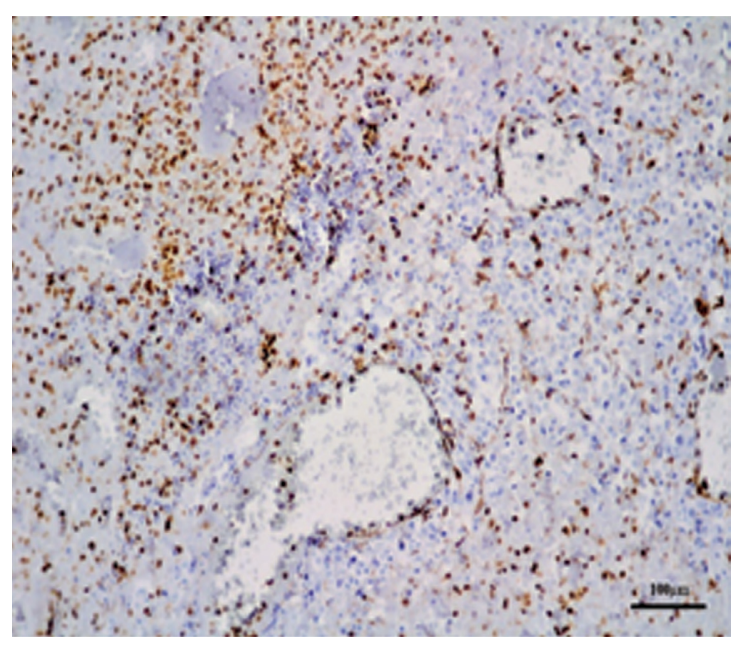

Figure 5. Mamary gland, Vimentin (Immunohistochemistry; Bar-100 $\mu \mathrm{m}$ )

The immunohistochemical method confirmed the presence of tumor epithelial cells in all of the examined tissues. More than $95 \%$ of neoplastic epithelial cells expressed cytokeratins in their cytoplasm (Fig. 7). Vimentin was moderately expressed in the cytoplasm of the mesenchymal cells as myoepithelial cells, lymphocytes and stromal connective tissue cells (Fig. 5). Ki-67 antibody showed a moderate proliferative index and was mostly noticed in the mitotic cells (Fig. 6).

Based on the macroscopic, histopathological and immunohistochemical findings the case was diagnosed as a simple tubular mammary carcinoma with metastasis to the liver, spleen, uterus, lungs and the heart.

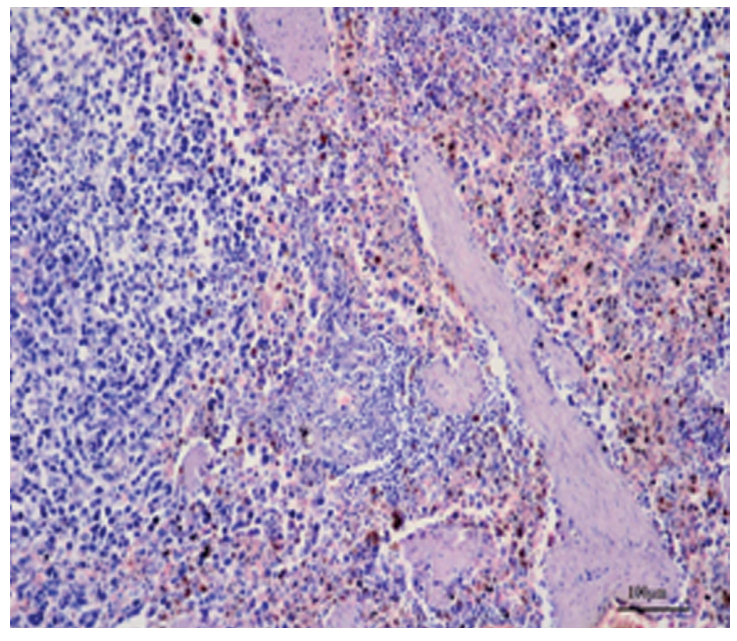

Figure 4. Spleen, haemosiderosis with tumor epithelial cells (H\&E., Bar-100 $\mu \mathrm{m})$

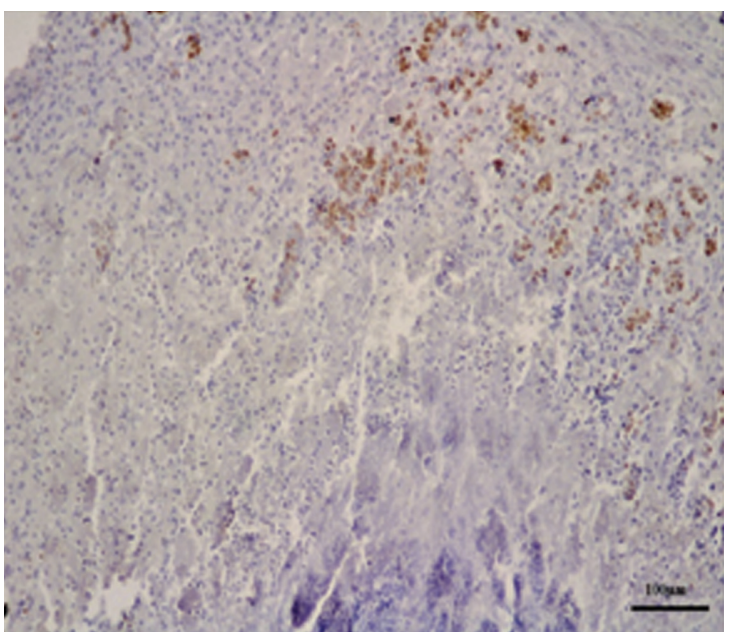

Figure 6. Mamary gland, Ki-67

(Immunohistochemistry; Bar-100 $\mu \mathrm{m}$ )

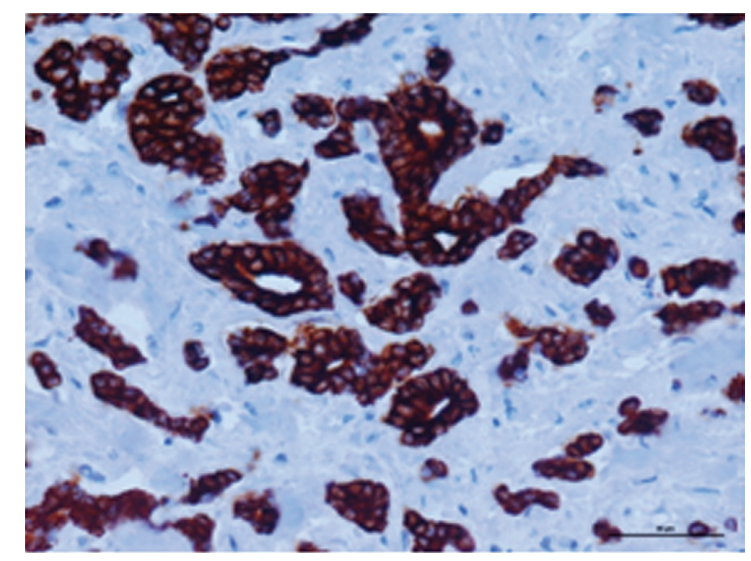

Figure 7. Mamary gland, CK AE1_AE3 (Immunohistochemistry; Bar-100 $\mu \mathrm{m}$ ) 


\section{DISCUSSION}

This article described the postmortem examination of a 15 years old lioness (Panthera $l e o$ ), as well as the histopathological and immunohistochemical findings. According to these findings, it is evident that the lioness suffered from carcinoma of the mammary gland. The examined parenchymatous organs had changes that are specific for tumor metastases. There was a close correlation between the tumor lesions and the expression of tumor markers in the examined tissues. The distribution of the tumor markers in the examined tissues was determined by the immunohistochemical method. Both methods provide reliable results in the diagnostics of tumors $(8,9)$.

All of the used primary antibodies were positive for this examination. Cytokeratins are intermediate filaments characteristically found in epithelial cells and their tumors (16). Therefore, cytokeratin AE1/ AE3 has been widely used for detection of the epithelial origin of malignant cells in tumors (17). Previous examinations show that the cytokeratins AE1/AE3 are expressed in all cases of canine mammary sarcoma including in situ carcinoma, complex carcinoma, tubulopapillary carcinoma, solid carcinoma and carcinosarcoma, except in the spindle cell carcinoma (18). In this examination, cytokeratin AE1/AE3 stained the cytoplasm of the epithelial tumour cells. Intermediate filament vimentin is used to mark nonmuscle sarcomas in dogs (10). Increased vimentin expression is associated with bad prognosis (12). Vimentin is a marker which appears positive mostly in malignant tumors in the feline species $(11,19,20)$ and therefore in wild lions. The vimentin expression in this case corresponds to previous investigations, where vimentin expression is positive in aggressive breast cancers with a size diameter bigger than 5,43 $\mathrm{cm}$ and with a high mitotic rate (11). The expression of Ki-67 is strongly associated with tumor cell proliferation and growth, and is widely used in routine pathological investigation as a proliferation marker and prognostic factor (13). There was a strong correlation between vimentin and $\mathrm{Ki}-67$ expression in the examined tissues which has been previously noticed (12).

Tumors of the mammary gland are frequent neoplasms in cats (3), and mammary adenocarcinomas are the most often form of mammary neoplasia in lions (6). Ocular melanoma and mammary mucinous carcinoma with metastasis on the lungs in an African lion (14), intestinal adenocarcinoma with diffuse peritoneal carcinomatosis in a lion (15) etc. were previously described, but there are no reports of mammary adenocarcinoma with widespread metastasis in wild felids.

\section{CONCLUSION}

This is a rare case of mammary carcinoma with widespread metastasis in other organs in an African female lion (Panthera leo). The symptomatology of adenocarcinoma is not always obvious, and that's why regular examinations are necessary in domestic as well as captive animals. Histopathoology and immunohistochemistry are usefull tools for tumor diagnosis and determination of the origin of tumour cell types in tumor metastasis.

\section{CONFLICT OF INTEREST STATEMENT}

The authors declared that they have no potential conf lict of interest with respect to the authorship and/or publication of this article

\section{ACKNOWLEDGEMENT}

The authors are grateful to the staff of the Zoo Garden Skopje and to the Institute of Pathology, Faculty of Medicine, Ss. Cyril and Methodius University, Skopje, Republic of North Macedonia for their cooperation in the preparation of this article.

\section{REFERENCES}

1. Vail, D. M., Mac Ewen, E.G. (2000). Spontaneously occurring tumors of companion animals as models for human cancer. Cancer Invest. 18(8): 781-792. https://doi.org/10.3109/07357900009012210 PMid:11107448

2. Misdorp, W. (2002). Tumors of the mammary gland. In: Meuten DJ. (Ed.), Tumors in domestic animals (pp. 575-606). 4th ed. Ames, USA: Iowa State Press. https://doi.org/10.1002/9780470376928.ch12

3. Schmidt, R. E., Langham, R. F. (1967). A survey of feline neoplasms. J Am Vet Med Assoc. 151, 13251328 .

4. Hayden, D. W., Nielsen, S. W. (1971). Feline mammary tumors. J Small Anim Pract. 12, 687-698. https://doi.org/10.1111/j.1748-5827.1971.tb06197.x PMid:4335377

5. Weijer, K., Head, K. W., Misdorp, W., et al. (1972). Feline malignant mammary tumors. I. Morphology 
and biology: some comparisons with human and canine mammary carcinomas. J Natl Cancer Inst. 49, 1697-1704.

https://doi.org/10.1093/jnci/49.6.1697 PMid:4346020

6. Ryan, A. S., Linden, E. C., Edward, C. R., Kelly H., Darin C., Michael, M. G. (2016). Clinicopathologic features of mammary masses in captive lions (Panthera Leo). Journal of Zoo and Wildlife Medicine 47(1): 127-131.

https://doi.org/10.1638/2015-0087.1 PMid:27010273

7. Gilette, D. M., Acland, H. M., Klein, L. (1991). Ductular mammary carcinoma in a lioness. J Am Vet Med Assoc. 173, 1099-1102.

8. Misdorp, W., Else, R. W., Hellmen, E., et al. (1999). Histological classification of mammary tumors of the dog and the cat. 2nd ed. Washington, USA: Armed Forces Institute of Pathology 3-29.

9. Misdorp, W., Cotchin, E., Hampe, J. F., et al. (1971). Canine malignant mammary tumors: I. Sarcomas. Vet Pathol. 8(2): 99-117.

https://doi.org/10.1177/030098587100800202 PMid:4367432

10. Fox, D. B., Cook, J. L., Kreeger, J. M., Beissenherz, M., Henry, C. J. (2002). Canine synovial sarcoma: a retrospective assessment of described prognostic criteria in 16 cases (1994-1999). J Am Anim Hosp Assoc. 38, 347- 355.

https://doi.org/10.5326/0380347 PMid: 12118688

11. Niveditha, S. R, Bajaj, P. (2003). Vimentin expression in breast carcinomas. Indian $\mathrm{J}$ Pathol Microbiol. 46, 579-584.

12. Hemalatha, A., Suresh, T. N., Harendra, K. M. L. (2013). Expression of vimentin in breast carcinoma, its correlation with Ki-67 and other histopathological parameters. Indian J Cancer. 50, 189-194. https://doi.org/10.4103/0019-509X.118724 PMid:24061457

13. Lian T. L., Guan, J., Qian, C., Jun, N. Z. (2015). Ki67 is a promising molecular target in the diagnosis of cancer. Mol Med Rep.11, 1566-1572.

https://doi.org/10.3892/mmr.2014.2914 PMid:25384676
14. Cagnini, D. Q., Salgado, B. S., Linardi, J. L., Grandi, F., Rocha, R. M., Rocha, N. S., Teixeira, C. R., Del Piero, F., Sequeira, J. L. (2012). Ocular melanoma and mammary mucinous carcinoma in an African lion. BMC Veterinary Research 8, 176.

https://doi.org/10.1186/1746-6148-8-176 PMid:23009723 PMCid:PMC3517319

15. Sonmez, G., Aytug, N., Akkoc, A., Cihan, H., Alasonyalilar, A. (2018). Intestinal adenocarcinoma with diffuse peritoneal carcinomatosis in a lion (Panthera leo). Eur J Wildl Res. 54, 385-389.

https://doi.org/10.1007/s10344-007-0151-x

16. Riccardi, E., Greco, V., Verganti, S., Finazzi, M. (2007). Immunohistochemical diagnosis of canine ovarian epithelial and granulosa cell tumors. J Vet Diagn Invest. 19, 431-435.

https://doi.org/10.1177/104063870701900418 PMid:17609358

17. Toniti, P., Sirivisoot, S., Jandee, P., Srimontri, P., Puchadapirom, P., Doungchawee, G., Kasorndorkbua, C. (2010). AE1/AE3, Vimentin and p63 Immunolocalization in canine mammary gland tumours: roles in differentiation between luminal epithelial and myoepithelial lineages. Asian Pac. J. Cancer Prev. 11, 227-230.

18. Aydogan, A., Metin, N. (2013). Detection of cell origin by immunohistochemistry in canine mammary tumours. Revue Méd. Vét. 164, 7, 395399.

19. Caliari, D., Zappulli, V., Rasotto, R., Cardazzo, B., Frassineti, F., Goldschmidt, M. H., Castagnaro, M. (2014). Triple-negative vimentin-positive heterogeneous feline mammary carcinomas as a potential comparative model for breast cancer. BMC Vet Res. 10, 185.

https://doi.org/10.1186/s12917-014-0185-8 PMid:25249140 PMCid:PMC4180584

20. Karabolovski, N., Gudan Kurilj, A., Severin, K., Hohsteter, M., Sostaric Zuckermann, I.C., Medveny, L., Artuković, B., Grabarevic, Z. (2016). Immunohistochemical study of epithelialmesenchymal transition in feline mammary tumours. Journal of Comparative Pathology 154(1): 114. https://doi.org/10.1016/j.jcpa.2015.10.145 